\title{
Serological Survey of Hydatid Disease in Asymptomatic Peoples in Mosul City, Iraq
}

\author{
*Abdulsalam Al-Mukhtar \\ Ikram K. Qasim \\ Department of Microbiology/College of Medicine/University of Mousl \\ *E-mail: salam-1943@yahoo.com
}

(Received 26/6/2013; Accepted 28/10/2013)

\begin{abstract}
Hydatidosis is one of the major zoonotic diseases that causes considerable economic losses and public health problems worldwide. This study was conducted in order to determine the seropositivity of hydatid disease in apparently healthy individuals who are attending the main blood bank in Mosul City. Therefore, enzyme linked immunosorbent assay (ELISA) was used in this study and to find a relation between the seropositivity and age, gender, occupation and educational level and to monitor the impact of the control programs for the disease in Mousl City. The study was conducted during 9 months period extended from November 2012 to July 2013.The samples of the study were composed of 480 apparently healthy individuals with ages ranging between 18-60 years, 280 male and 200 female. Serum samples were obtained from the main blood bank in Mosul city, ELISA test was used for detecting specific anti Echinococcus granulosus antibodies in patients' sera. ELISA kits used were (Echinococcus ELISA IgG- IBL, Hamburg, Germany -RE 56201) kits.

The results revealed that out of 480 cases only $24(5 \%)$ were positive by ELISA, the most frequently infected individuals were females $(8 \%)$ while males were less frequently encounter the disease $(2.86 \%)$. the rate of hydatid cysts was highest at age group $21-30$ years $(7.02 \%)$ followed by age group 31-40 years $(6.5 \%), 41-50$ years $(3.7 \%)$ respectively, the highest infection rate was reported among housewives $(10.83 \%)$, followed by self employed $(4.46 \%)$, then the government employed $(3.23 \%)$. On the other hand the lowest rate of infection was recorded among students $(1.28 \%)$ and $(2.88 \%)$ in other occupations, it was reported that $(56.5 \%)$ were illiterate, $(4.35 \%)$ were primary school, $(2.42 \%)$ were secondary school and $(1.38 \%)$ were of high education, most of the seropositive individuals were from rural or semi-rural areas surrounding Mosul City. It was recorded that $(6.02 \%)$ and $(3.89 \%)$ were from rural and urban area respectively. The rate of seropositivity in the individuals who have contact with dogs $(5.81 \%)$ was higher than that in individuals who do not have contact with dogs $(4.05 \%)$.
\end{abstract}

Keywords: Cystic Echinococcosis, ELISA, Mosul city.

\section{التحري المصلي لمرض الكيلس المائية للأشخاص الأصحاعظالهربافي مدينة الموطل \\ المالخص}

داء العداري هو ولحد من الأمراض الحيوانية المنشأ الرئيسية التي تسبب غشائر القتصاية كبيرة ومشلل صحية العلمة

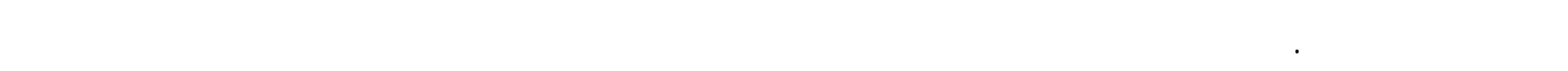

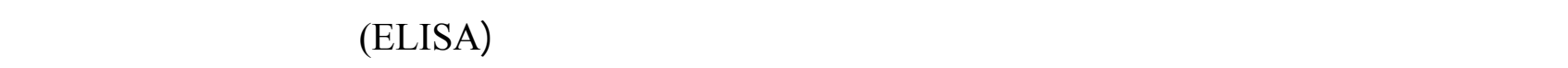

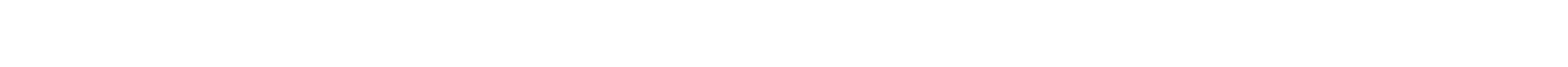

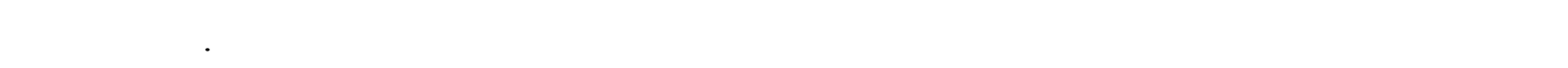

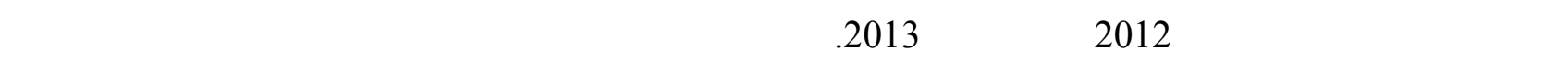
الرئيسي في مدينة الموصل حيثشملت العينت 480 عينة: 280 عينة مم للذكور و 200 عينة دم للإنت الأصحاءظاهريا 
بأعمار تتراوح مابين 18 -60سنة. وكانت لطمقم فحص مقليسة الممتز المناعي المرتط بالأذزيم تستخدم مجموعات (المشوكة

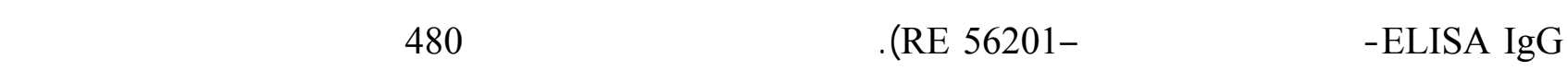

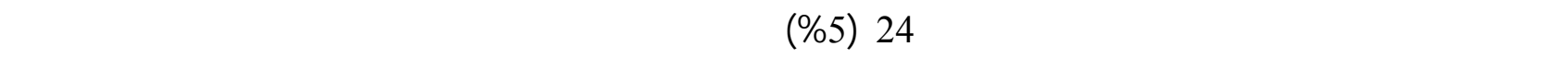

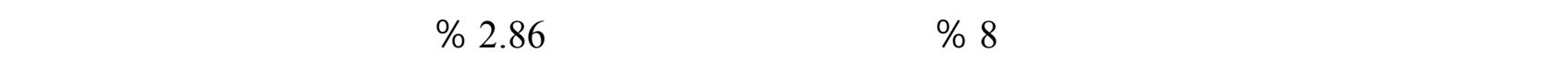

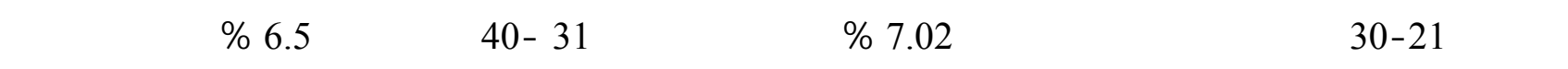

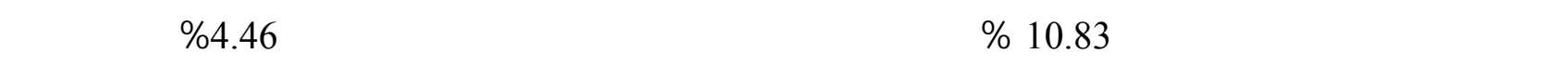

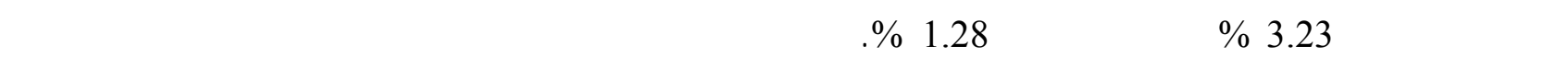

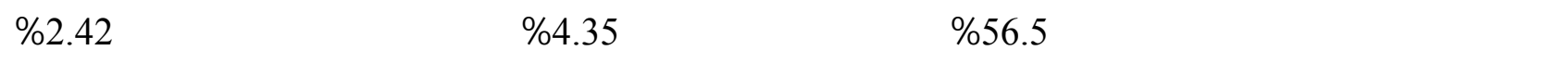

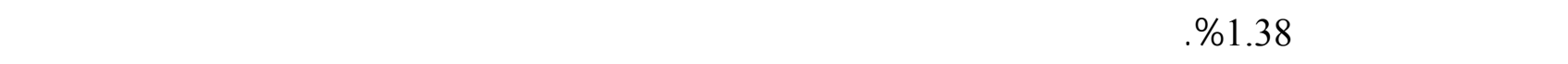

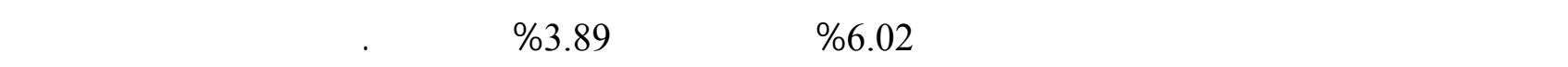

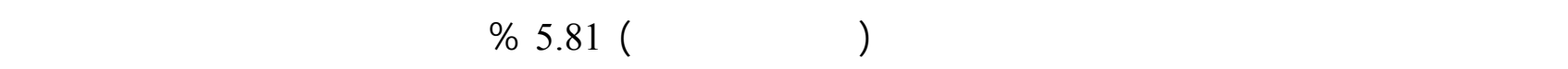

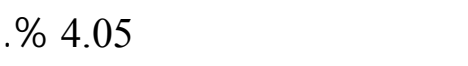

الكالت الدالة: الأكيلس العدارية، فحص مقليسة الممتز المناعي المرتبط بالإنزم، مدينة الموصل.

INTRODUCTION

Hydatid cyst (HC) or hydatidosis or cystic echinococcosis(CE) is a serious helminthic zoonotic disease that possesses an important economic and public health concern in rural and urban areas (Galindo et al., 2002). It has a public health importance not only in areas of endemicity but also in countries or regions without endemicity due to the migration of infected people and livestock exchange (Khabiri et al., 2007).

$\mathrm{CE}$ is a disease caused by the larval (metacestode) stage of Echinococcus granulosis which is the main species pathogenic for man and lives in the gut of the dog and other carnivorous animals representing the definitive hosts, or involves intermediate hosts in both domestic and wild animals. Human becomes an accidental intermediate hosts by ingesting taenia eggs(Thompson and McManus,2002). E.granulosus has a worldwide distribution and endemic in sheep and cattle breeding countries. Iraq is regarded as an endemic region of hydatidosis and the disease has been reported more or less throughout the country (Moro and Schantz, 2009). Persons with CE often remain asymptomatic until hydatid cysts containing the larval parasites grow large enough to cause discomfort, pain, nausea, and vomiting. The hydatid cysts grow over a period of several years before reaching maturity and the rate at which symptoms appear typically depends on the location of the cyst (McManus and Thompson, 2003). The hydatid cysts are mainly found in the liver and lungs but can also appear in the spleen, kidneys, heart, bone, and central nervous system, including the brain and eyes (Geramizadeh, 2013). Non-invasive imaging techniques such as ultrasound, CT scans and MRI imaging are all used for detecting and defining the extent of a vascular fluid-filled cysts in most organs. These techniques have been proved to be valuable for diagnosis and preoperative evaluation (Moro et al., 2011). Serological tests are important in the diagnosis of hydatid disease, and they help in the detection of cases and in the sero-surveillance of hydatid disease in the community. Hydatid serology is based largely on the detection of circulating hydatid antibodies in the serum which occur frequently in established cystic hydatid infections (Carmena et al., 2006).

In the past, surgery was the only treatment for CE. Chemotherapy and PAIR (Percutaneous Aspiration, Injection of chemicals and Reaspiration) have been used to replace surgery as an 
effective treatment for CE (Akarsu et al., 2005). However, surgery remains the most effective treatment to remove hydatid cyst and can lead to a complete cure (Martn, 2000).

\section{MATERIAL AND METHOD}

The present study was conducted during 9 months extended from September 2012 to May 2013. The samples of the study composed of 480 apparently healthy individuals with age 18-60 years, 280 male and 200 female. Sera Samples were obtained from the main blood bank in Mosul City. From each participant, $3 \mathrm{ml}$. of venous blood was withdrawn and transferred into conical centrifuge tubes, then centrifuged for 5 minutes at $(450 \mathrm{rpm})$. The serum was stored at $-20 \mathrm{C}^{\mathrm{o}}$ until used.

We used ELISA test for detecting specific anti Echinococcus granulosus antibodies in patients' sera. Before assaying, all serum samples have been diluted with diluent buffer (contains: PBS, BSA, $<0.1 \% \mathrm{NaN} 3$ ) in a relation of $1: 100$. Then Pipette $100 \mu \mathrm{L}$ of each standard and diluted sample in to the respective wells of the microtiter plate, wells are incubated for 1 hour at $18-25^{\circ} \mathrm{C}$, wells were washed 3-times with $300 \mu \mathrm{L}$ of diluted wash buffer, then $100 \mu \mathrm{L}$ of Echinococcus antiIgG Enzyme conjugate was dispensed in to each well, $100 \mu \mathrm{L}$ of TMB substrate solution was dispensed into all wells, incubate $20 \mathrm{~min}$. at $18-25^{\circ} \mathrm{C}$, stop the substrate reaction by adding $100 \mu \mathrm{L}$ of TMB stop solution into each well, color changes from blue to yellow. The optical density has been read at $450 \mathrm{~nm}$ with automated device and the results were calculated.

\section{Statistical analysis}

The chi-square test which is a non-parametric test was used to find the statistical differences between groups of population to decide whether or not effects are present (Milton, 1983). The interpretation of the results were done through the measurement of P-value with a statistically significant effect when P-value is $<0.05$ (Hopkins, 2002).

\section{RESULTS}

The results revealed that out of 480 cases only 24 ( $5 \%$ ) were positive by ELISA, The cut-off point between clusters (set at 2.0 standard deviations from the mean of the seronegatives) was 0.3 , The results revealed that out of 480 cases only 24 ( $5 \%$ ) were positive by ELISA, these results showed that the most frequently infected individuals were females ( $8 \%$ ) while males were less frequently encounter the disease ( $2.86 \%)$. The difference between male and female seropositivity was statistically highly significant $(\mathrm{P}-$ Value $\leq 0.01$ ), as shown in (Table 1 ).

Table 1: Distribution of seropositivity of hydatid cysts using ELISA according to gender $(\mathrm{n}=\mathbf{4 8 0})$

\begin{tabular}{|c|c|c|c|c|c|c|}
\hline \multirow{2}{*}{ Sex } & \multicolumn{2}{|c|}{ positive } & \multicolumn{2}{c|}{ Negative } & \multicolumn{2}{c|}{ Total } \\
\cline { 2 - 7 } & No. & \% & No. & \% & No. & \% \\
\hline Male & 8 & 2.86 & 272 & 97.1 & 280 & 58.3 \\
\hline Female & 16 & 8 & 184 & 92 & 200 & 41.7 \\
\hline Total & 24 & 5 & 456 & 95 & 480 & 100 \\
\hline
\end{tabular}

Chi-Sq $=6.496$, DF $=1$, P-Value $\leq 0.01$

The seropositivity of hydatid cysts according to age distribution found that the rate of hydatid cysts was highest at age group 21-30 years (7.02\%) followed by age group 31-40 years (6.5\%). While the lowest number of hydatid cysts was recorded in age group $18-20$ years $(1.61 \%)$. The seropositivity among different age groups was statistically very highly significant (P-Value $\leq 0.001$ ), as shown in (Table 2). 
Table 2: Distribution of seropositivity of hydatid cysts using ELISA according to age group (yr). $(n=480)$

\begin{tabular}{|c|c|c|c|c|c|c|}
\hline \multirow{2}{*}{$\begin{array}{c}\text { Age } \\
(\text { yr })\end{array}$} & \multicolumn{2}{|c|}{ positive } & \multicolumn{2}{c|}{ Negative } & \multicolumn{2}{c|}{ Total } \\
\cline { 2 - 7 } & No. & \% & No. & \% & No. & \% \\
\hline $18-20$ & 1 & 1.61 & 61 & 98.4 & 62 & 12.9 \\
\hline $21-30$ & 12 & 7.02 & 169 & 98.8 & 171 & 37.7 \\
\hline $31-40$ & 8 & 6.5 & 111 & 90.2 & 123 & 24.8 \\
\hline $41-50$ & 1 & 3.7 & 26 & 96.8 & 27 & 5.6 \\
\hline $51-60$ & 2 & 2.06 & 89 & 91.3 & 97 & 18.9 \\
\hline Total & 24 & 5 & 456 & 95 & 480 & 100 \\
\hline
\end{tabular}

Chi-Sq $=14.886, \mathrm{DF}=4, \mathrm{P}-$ Value $\leq 0.001$

Regarding the occupation, it was found that the highest infection rate was reported among housewives in 13 cases ( $10.83 \%$ ), followed by self employed in 5 cases $(4.46 \%)$, the lowest rate of infection was recorded among the students in 1 case $(1.28 \%)$. The difference between occupation and seropositivity was statistically highly significant $(\mathrm{P}-$ Value $\leq 0.01)$, as shown in (Table 3 ).

Table 3: Distribution of seropositivity of hydatid cysts using ELISA according to occupation $(n=480)$

\begin{tabular}{|c|c|c|c|c|c|c|}
\hline \multirow{2}{*}{ Occupation } & \multicolumn{2}{|c|}{ positive } & \multicolumn{2}{c|}{ Negative } & \multicolumn{2}{c|}{ Total } \\
\cline { 2 - 7 } & No. & \% & No. & \% & No. & \% \\
\hline $\begin{array}{c}\text { Government } \\
\text { employed }\end{array}$ & 1 & 3.23 & 30 & 96.77 & 31 & 6.45 \\
\hline Self employed & 5 & 4.46 & 107 & 97.18 & 112 & 23.34 \\
\hline Housewives & 13 & 10.83 & 107 & 89.16 & 120 & 25 \\
\hline Students & 1 & 1.28 & 77 & 98.7 & 78 & 16.24 \\
\hline Others & 4 & 2.88 & 135 & 28.1 & 139 & 28.93 \\
\hline Total & 24 & 5 & 456 & 95 & 480 & 100 \\
\hline
\end{tabular}

Chi-Sq $=12.458, \mathrm{DF}=4, \mathrm{P}-$ Value $\leq 0.01$

Regarding the educational status, it was clear from the results that the seropositivity was higher among illiterate than literate individuals, and it was reported that 13 cases $(56.5 \%)$ were illiterate. The differences between the level of education and seropositivity were statistically very highly significant (P-Value $<0.001$ ), as shown in (Table 4).

Table 4: Distribution of seropositivity of hydatid cysts using ELISA according to education $(n=480)$

\begin{tabular}{|c|c|c|c|c|c|c|}
\hline \multirow{2}{*}{ Level of Education } & \multicolumn{2}{|c|}{ Positive } & \multicolumn{2}{c|}{ Negative } & \multicolumn{2}{c|}{ Total } \\
\cline { 2 - 7 } & No. & $\%$ & No. & $\%$ & No. & \% \\
\hline Illiterate & 13 & 56.5 & 10 & 43.48 & 23 & 23.9 \\
\hline Primary school & 5 & 4.35 & 110 & 95.65 & 115 & 25.8 \\
\hline secondary school & 3 & 2.42 & 121 & 97.58 & 124 & 45.4 \\
\hline High education & 3 & 1.38 & 215 & 98.6 & 218 & 100 \\
\hline Total & 24 & 5 & 456 & 95 & 480 & \\
\hline
\end{tabular}


The results showed that according to residence most of the seropositive individuals were from rural or semi-rural areas surrounding Mosul City. It was recorded that 15 cases $(6.02 \%)$ and 9 cases $(3.89 \%)$ were from rural and urban areas respectively. These results were statistically not significant (P-Value $>0.05$ ), as shown in (Table 5).

Table 5: The distribution of seropositivity of hydatid cysts using ELISA according to residence $(\mathbf{n}=\mathbf{4 8 0})$

\begin{tabular}{|c|c|c|c|c|c|c|}
\hline \multirow{2}{*}{ Residence } & \multicolumn{2}{|c|}{ Positive } & \multicolumn{2}{c|}{ Negative } & \multicolumn{2}{c|}{ Total } \\
\cline { 2 - 7 } & No. & \% & No. & \% & No. & \% \\
\hline Urban & 9 & 3.89 & 222 & 96.1 & 231 & 48.1 \\
\hline Rural & 15 & 6.02 & 234 & 93.98 & 249 & 51.8 \\
\hline Total & 24 & 5 & 456 & 95 & 480 & 100 \\
\hline
\end{tabular}

Chi-Sq $=1.142, \mathrm{DF}=1, \mathrm{P}-$ Value $>0.05$

Regarding the history of individuals and their contact with dogs and other livestock. The rate of seropositivity in the individuals who have contact with dogs $15(5.81 \%)$ was higher than that in individuals who have no contact with dogs $9(4.05 \%)$. The relation between animal contact and seropositivity was statistically significant (P-Value $<0.05$ ), as shown in (Table 6).

Table 6: Distribution of positive cases of hydatidosis using ELISA according to animal contact $(n=480)$

\begin{tabular}{|c|c|c|c|c|c|c|}
\hline \multirow{2}{*}{$\begin{array}{c}\text { Contact with } \\
\text { dogs }\end{array}$} & \multicolumn{2}{|c|}{ positive } & \multicolumn{2}{c|}{ Negative } & \multicolumn{2}{c|}{ Total } \\
\cline { 2 - 7 } & No. & \% & No. & \% & No. & \% \\
\hline Yes & 15 & 5.81 & 243 & 94.18 & 258 & 53.7 \\
\hline No & 9 & 4.05 & 213 & 95.94 & 222 & 46.3 \\
\hline Total & 24 & 5 & 456 & 95 & 480 & 100 \\
\hline
\end{tabular}

Chi-Sq $=4.616, \mathrm{DF}=1, \mathrm{P}-$ Value $<0.05$

\section{DISCUSSION}

The present study shows that the seropositivity among females ( $8 \%$ ) was significantly higher $(\mathrm{P} \leq 0.01)$ than in males $(2.86 \%)$. The high infection rate in females is in agreement with most of other studies in Iraq. Mohammed, (2013) showed that the seropositivity in females (2.8\%) was higher than in males (1.6\%). Kadir et al., (2006) also stated that the higher rate of hydatid cysts was in females $(58.4 \%)$ than males $(41.6 \%)$. Abbas et al., (2011) stated that most of the infected patients were females where the percentage of the females infection was $50.00 \%$ more than that of the males which was $36.17 \%$. Sex differences may be attributed to epidemiological factors such as socio-cultural and occupational risk due to the fact that most women are housewives and more closely associated with the sources of infection such as infected soil, water and vegetable contamination and also work at livestock breeding and agriculture in rural areas.

The age of individuals in the present study vary between (18-60) years. The maximum seropositivity recorded was among patients in the third decade $21-30$ years $(7.02 \%)$ followed by the fourth decade 31-40 years (6.5\%) was found in Mosul city. The seropositivity among different age groups was statistically very highly significant $(\mathrm{P}-\mathrm{Value} \leq 0.001)$. Similar findings were reported by Al-barwari et al., (1991), who found that the peak age of incidence in Erbil province lays in the second decade for males and in the third decade for the female patients and it lays in the third decade irrespective of the sex. Kadir et al., (2006) stated that the age distribution of hydatid disease 
was between (21-30) years old. In epidemiological study of hydatid disease on 157 patients underwent surgical treatment in Karbala province, Al-Garrawi, (2008) found that the infection rate was higher among age group between (22-32) years (28.7\%). Nearly similar results were obtained by Al-Obaidi et al., (2008) in a descriptive study has been done on (81) patients with hydatid disease in Tikrit, they found that the most frequent age affected among female patients was between (41-50) years. These differences in the age groups might be due to the time of ingestion of the egg of E.granulosis and the rate of development of the cyst, which persists for many years to manifest clinically and that hydatidosis is a disease of long incubation period (probably 20 to $30 \mathrm{yrs}$ ) and accordingly, a wide range of different ages is obvious in infected patients.

The present study found that the highest seropositivity was among housewives in 13 cases $(10.83 \%)$ followed by self employed in 5 cases $(4.46 \%)$. This observation was in agreement with other studies. Al-barwari et al ., (1991), found that 58 cases $(70.7 \%)$ were identified as housewives. Saida and Nouraddin, (2011) stated that the percentage of hydatid disease patients according to their occupations was being higher among the housewives 53 (34.64\%), this may be due to the close contact of these women with the sources of infection, such as soil or vegetables contaminated with eggs of E. granulosus from dog feces.

The present study recorded that the seropositivity was higher among illiterate than literate individuals ,and reported that 13 cases $(56.5 \%)$ were illiterate, 5 cases $(4.35 \%)$ were primary school, 3 cases $(2.42 \%)$ were secondary school and 3 cases $(1.38 \%)$ were of high education which was statistically highly significant $(\mathrm{P} \leq 0.001)$. Mohammed, (2013) stated that the prevalence of CE had a significant relationship with the level of education, among 15 infected persons in Sulaimania $9(60 \%)$ were illiterate. Awatif, (1999) in a descriptive study in Saudi Arabia on 67 patients, 43 $(64.2 \%)$ were illiterate, $13(19.4 \%)$ could read and write, and only 11(16.4\%) had education beyond primary school. In Iran, Shahrokhabadi et al., (2013) stated that the seroprevalence of hydatid disease was $2.1 \%$ in illiterate people which showed the highest rate. These findings support the relation between personal knowledge, hygiene and chance of getting infection. Hydatid disease is preventable, and education is one of the most effective tools to achieve this. It is important that health authorities take a responsible attitude towards increasing community awareness, and implement control strategies through education.

The present study found that most of the seropositive individuals were from rural or semirural areas surrounding Mosul City. It was recorded that $15(6.02 \%)$ and $9(3.89 \%)$ were from rural and urban areas respectively. These results were statistically not significant $(\mathrm{P}>0.05)$. This result is supported by many researches, where they found that the infection rate in rural areas was higher than that in urban areas. Saida and Nouraddin, (2011) showed that among 149 patients according to their residence, the result showed that, $82(55.03 \%)$ were in areas around or outside the city (rural) while the others 67 (44.97\%) lived in areas inside the city (urban). Al-Obaidi et al., (2008) have been documented that $(62.9 \%)$ of patients were from rural areas. A retrospective study in Basra of 300 patients with pulmonary hydatid cyst disease found that the majority of the patients (74\%) were from rural areas (Benyan et al., 2013). The high infection rate in rural areas may be due to many factors including poor living conditions and lack of adequate health education in rural areas and economic instability and financial restrictions in control and prevention.

The present study showed that the seropositivity was more common (5.81\%) among individuals who had direct contact with dogs. The relation between animal contact and seropositivity was statistically significant $(\mathrm{P}<0.05)$. A similar pattern was observed by other studies in Iraq. Abdullah and Jarjees, (2005) studied the worm burden and egg count of E. granulosus in stray dogs of Mosul City, where 120 adult stray dogs were killed and necropsied for detection of the actual number of E.granulosus along the small intestine, results revealed that worm loads ranged between 52 to 2000 worms with an average 1026 worm per dog. The commonest site of worms was the second third of the small intestine (75\%). The number of ova observed in the uteri of a gravid segment was 80 to more than 3000 . They showed that $16.66 \%$ of the dogs harbor the cestode. 


\section{CONCLUSION}

From the present study, we conclude that ELISA test for CE represents a rapid and informative method for an early detection of hydatid cyst in the vital organs (liver, lung, brain,..) by ELISA then confirms the result by doing other investigations like ultrasound and computerized tomography (CT scan) for an early treatment of the disease by chemotherapy before the need of surgery. So that ELISA screening technique for hydatid cyst infection for healthy blood donors should be done routinely.

\section{REFERENCES}

Abbas, F.; Issa, A.B.; Al-Ghozi, Z.S. (2011). Epidemiological study of rabies Hydatid disease of aladret bags in Dhi Qar governorate. College of Education J., 3(1), 121 132.

Abdullah, I.A.; Jarjees, M.T. (2005). Worm Burden, Dispersion and Egg Count of Echinococcus granulosus in Stray Dogs of Mosul City, Iraq. Raf. J. Sci., 16(8), Biology, Special Issue, 8-13.

Akarsu, M.; Kantar, F.U.; Gülcü, A. (2005). Echinococcosis . JMRI; 26(4), 287-295.

Al-Barwari, E.; Saeed, S.; Khalid, W.; Al-Harmani, L. (1991). Human Hydatidosis in Arbil, N. Iraq. J. Islamic Academy of Sci.; 4(4), 330-335.

Al-Garrawi, A.K. (2008). Epidemiological study of hydatid disease in patients underwent Surgical treatment in Al - Hussain - General Hospital / Karbala. Karbala Sci. J., 6(3), 88-93.

Al-Obaidi, H.S.; Salman, A.; Arziak, Z. (2008). Epidemiology of hydatid cyst with experimental trial of the anti-parasitic activity of ivermectin in compare to other common antiparasitic drug. Tikrit Medical J., 14(1),1-11.

Awatif, A.A. (1999). Epidemiology of hydatid disease in Riyadh: a Hospial -based study. Annals Saudi Medicine, 19(5), 450-452 .

Benyan, K.Z.; Abdul Ameer, F.; Al-Hassani, A. (2013). Pulmonary Hydatid Cyst Disease in South of Iraq: Short Term Outcome After Surgical Intervention. JPMI; 27(2), 200 - 207.

Carmena, D.; Benito, A.; Eraso, E. (2006). Antigens for the immunodiagnosis of Echinococcus granulosus infection: an update. Acta Trop. ; 98, 74-86.

Galindo, M.; Gonzales, M.; Galanti, N. (2002). Echinococcus granulosus protoscolex formation in natural infections. Biol. Res., 35(3), 365-371.

Geramizadeh, B.M.D. (2013). Unusual Locations of the Hydatid Cyst: A Review from Iran. IJMS ; 38(1), 2.

Hopkins, W.G. (2002). A new view of statistics. Internet Society for Sport Science: http://www.sportsci.org/resource/stats/.

Kadir, M.; Adil , S.; Al-Den, S. Sh. (2006). Seropidemiology Of Human Hydatidosis In Kirkuk And Tikrit/ Iraq. J. Fac. Med. Baghdad, 48(4).

Khabiri, A.R.; Bagheri, F.; Siavashi, M.R.; Assma, M. (2007). Characterization of Specific IgE Antibody Related to Antigen 5 of Echinococcus granulosus. Iranian J. Publ. Health, 36(1), 22-50.

Martn, B. (2000). "An Introduction to Medical Statistic". 3rd edn. Oxford University press; chapter 7.

McManus, D.P.; Thompson, R.C.A. (2003). Molecular epidemiology of cystic echinococcosis. Parasitology, 127, 37-51.

Milton, J.S.; Tsoko, J.O. (1983). Statistical methods. Biological and health Sci., 20, 383-93.

Mohammed, M.O. (2013). The Human Seroprevalence of Echinococcus Granulosus in Sulaimani Governorate. The Iraqi Postgraduate Medical J., 12(1), 45-50.

Moro, P.L; Budke, C.M.; Schantz, P.M.; Vasquez, J.; Santivan, S.J.; Villavicencio, J. (2011). Economic Impact of Cystic Echinococcosis in Peru. Neglected Tropical Disease. 5(5), e1179.

Moro, P.; Schantz, P.M. (2009). Echinococcosis: a review. Int. J. Infect. Dis., 13, 125-133. 
Saida, L.A.; Nouraddin, A.S. (2011). Epidemiological study of cystic echinococcosis in Man and slaughtered Animals in Erbil province, Kurdistan Regional-Iraq. Tikrit J. Pure Sci., 16(4), 4550 .

Shahrokhabadi, R.; Rahimi, E.; Poursahebi, R. (2013). Seroepidemiological study of human hydatidosis in Rafsanjan, Kerman. Zahedan J. Res. Med. Sci., 15(X), 50.16.

Thompson, R.C.; McManus, D.P. (2002). Towards a taxonomic revision of the genus Echinococcus. Trends Parasitol, 18. 